\title{
Peran Komunikasi Organisasi Dalam Meningkatkan Kinerja Karyawan PT. Fuji Dharma Electric Jakarta
}

\author{
Ahmad Rojikun
}

Program Studi S1 Manajemen, Fakultas Ekonomi dan Bisnis,Universitas Mohammad Husni Thamrin

Corresepondence author: Rojikun65@gmail.com

Received : 23 Juni 2021

Accepted : 24 September 2021

Published: 30 September 2021

DOI: https://doi.org/10.3701/ileka.v2i2.571

\begin{abstract}
ABSTRAK
Komunikasi didalam organisasi adalah hal yang mengikat pada kesatuan organisasi. Salah satu tantangan terbesar dalam komunikasi organisasi adalah bagaimana menyampaikan informasi ke seluruh bagian organisasi dan bagaimana menerima informasi dari seluruh bagian organisasi. Tujuan penelitian ini untuk mengetahui lebih dalam bagaimana Peran Komunikasi Organisasi Dalam Meningkatkan Kinerja Karyawan di PT. Fuji Dharma Electric Jakarta.Bilamana Informasi yang tersampaikan sesuai dengan kebutuhan, maka komunikasi yang dijalankan efektif akan secara otomatis menghasilkan suatu kinerja karyawan yang baik didalamnya. Penelitian ini menggunakan metode kualitatif fenomenologi adalah jenis penelitian yang berorientasi pada hasil filsafat. Filsafat yang dimaksud adalah upaya peneliti menggali informasi dengan cara mencari arti, makna secara esensinya, dimana pengumpulan datanya menggunakan teknik observasi, wawancara dan dokumentasi. Dalam teknik wawancara merupakan pembicaraan yang mempunyai tujuan dan didahului beberapa pertanyaan informal. Wawancara pada penelitian kualitatif merupakan pembicaraan yang mempunyai tujuan dan didahului beberapa pertanyaan informal.Sedangkan informan dipilih berdasarkan purposive sampling. Analisis data yang diperoleh menggunakan model Miles dan Huberman, dan keabsahan data diuji menggunakan triangulasi data/sumber. Hasil yang diperoleh menunjukkan bahwa komunikasi organisasi di PT.Fuji Dharma Electric telah efektif dilihat dalam indikator fungsi komunikasi organisasi sehingga berdampak pada kinerja karyawan yang baik/optimal.
\end{abstract}

Kata Kunci : Komunikasi Organisasi, Kinerja Karyawan.

\begin{abstract}
Communication within the organization is the thing that binds the unity of the organization. One of the biggest challenges in organizational communication is how to convey information to all parts of the organization and how to receive information from all parts of the organization. The purpose of this study is to find out more about the Role of Organizational Communication in Improving Employee Performance at PT. Fuji Dharma Electric Jakarta. If the information conveyed is according to needs, then effective communication will automatically produce a good employee performance in it. This study uses a qualitative method of phenomenology is a type of research-oriented philosophy results. The philosophy in question is the researchers' efforts to explore information by looking for meaning, meaning in essence, where data collection uses observation, interviews and documentation techniques. In the interview technique is a conversation that has a purpose and is preceded by several informal questions. Interviews in qualitative research are conversations that have a purpose and are preceded by several informal questions. While the informants are selected based on purposive sampling. Analysis of the data obtained using the Miles and Huberman model, and the validity of the data was tested using data/source triangulation. The results obtained indicate that organizational communication at PT. Fuji Dharma Electric has been effectively seen in the indicators of the organizational communication function so that it has an impact on good/optimal employee performance.
\end{abstract}

Keywords: Organizational Communication, Employee Performance. 


\section{PENDAHULUAN}

Manusia adalah mahluk yang hidup berkelompok bukan mahluk individu. Interaksi manusia dengan sesamanya merupakan fungsi komunikasi sebagai alat (instrument) yang dipakai manusia untuk melancarkan sebuah interaksi sosial antar individu dengan individu lainnya, juga individu dengan kelompok lainnya hingga antar sesama kelompok dengan kelompok lainnya. Komunikasi adalah suatu proses sosial yang sangat mendasar bahkan vital dalam keberlangsungan hidup manusia didalam masyarakat. Demikian juga didalam sebuah organisasi, komunikasi menjadi pondasi utama dalam keberlangsungan jalannya suatu organisasi, karena pada kenyataannya masalah komunikasi selalu muncul dalam suatu proses organisasi.

Terbentuknya sebuah organisasi yang kondusif merupakan hasil komunikasi yang efektif dalam organisasi,sebuah interaksi sosial antar individu dengan individu lainnya, juga individu dengan kelompok hingga antar sesama kelompok dengan kelompok lainnya. adanya perbedaan - perbedaan individu dan ketidak mengertian (mis-understanding) dalam organisasi dapat diminimalisir, sehingga kinerja seluruh karyawan dapat berlangsung dengan baik. Salah satu organisasi yang mengandalkan komunikasi organisasi dalam rangka mewujudkan tujuan mencapai visi dan misi hingga sampai menjaga keberlangsungan organisasi tersebut adalah PT.Fuji Dharma Electric yang berlokasi di Pulo Gadung Jakarta.

Selain diperlukannya sebuah komunikasi organisasi yang effektif dalam menjalankan suatu tujuan organisasi, di lain sisi adanya kinerja yang baik adalah salah satu stimulus untuk sebuah organisasi dalam menjaga eksistensinya. Salah satu faktor yang mempengaruhi kinerja pentingnya sebuah wewenang atasan yakni otoritas yang merupakan sifat dari suatu komunikasi atau perintah dalam suatu organisai formal yang dimiliki oleh suatu anggota organisasi kepada orang lain untuk melakukan suatu kegiatan kerja sesuai dengan kontribusnya. (Prawirosentono, 1999:27). Perintah tersebut mengatakan apa yang boleh dilakukan dan apa yang tidak boleh dilakukan.

Adapun bagaimana peran serta karyawan dalam mengelola program dan kegiatan organisasi sesuai apa yang telah menjadi job description serta pesan tugas dari jajaran pimpinan PT.Fuji Dharma Electric yang pada akhirnya membuat peneliti tertarik untuk mengkaji dan menguji keterkaitan Peran Komunikasi Organisasi dengan Kinerja Karyawan di PT.Fuji Dharma Electric Jakarta. Adanya struktur organisasi yang memiliki banyak badan dan letak yang berbeda-beda membuat koordinasi dalam sebuah organisasi pemerintahan atau perusahaan memerlukan sistem komunikasi yang baik. Komunikasi yang efektif merupakan usaha terbaik 
dalam mengoptimalkan koordinasi dan hubungan antar badan dalam organisasi pemerintahan atau perusahaan. Sehingga adanya komunikasi efektif secara otomatis menghasilkan kinerja karyawan yang baik. Maka dipilihnya judul ini oleh peneliti dimaksudkan untuk melihat dan mengetahui bagaimana sebuah pesan tugas dalam PT.Fuji Dharma Electric disampaikan dari komunikator/ jajaran pimpinan kepada komunikan/ jajaran staff sehingga pesan yang diterima bisa menjadi efektif dan dapat mengoptimalkan kinerja.

Mengenai kinerja karyawan Bernandin dan Russel dalam Sopiah (2008: 182) mengemukakan enam kriteria primer untuk mengukur prestasi kerja / kinerja karyawan, yaitu Quality, Quantity, Timeliness, Cost Effectiveness, Need for supervision dan terakhir Interpersonal impact.

\section{METODE}

Penelitian ini menggunakan metode Korelasional dengan pendekatan kuantitatif, pertimbangan menggunakan metode ini digunakan untuk: (1) Mengukur hubungan diantara variabel (2) Meramalkan variabel tak bebas dari pengetahuan kita tentang variabel bebas (Jalaluddin Rakhmat, 2007).

Populasi dalam penelitian ini adalah seluruh Karyawan PT.Fuji Dharma Electric yang berjumlah 32 karyawan, karena populasi tidak mencapai seratus maka tidak ditarik sampel untuk itu maka penelitian ini merupakan penelitian populasi dan teknik pengambilan sampel adalah sampel jenuh ialah teknik pengambilan sampel apabila semua populasi digunakan sebagai sampel. Teknik pengambilan data dengan menggunakan wawancara langsung dengan responden yaitu karyawan PT.Fuji Dharma Electric dengan menggunakan daftar pertanyaan atau kuesioner.

\section{HASIL DAN PEMBAHASAN}

Salah satu faktor yang turut menetukan pencapaian tujuan organisasi perusahaan adalah komunikasi organisasi. Komunikasi organisasi sangat berhubungan erat dengan efektivitas kinerja karyawan jika komunikasi organisasi berjalan dengan baik dan benar maka akan terjadi efektivitas kinerja karyawan. Secara umum dapat dikatakan bahwa komunikasi organisasi yang baik dan benar pada karyawan disuatu perusahaan mengindikasikan bahwa terjadi peningkatan kinerja karyawannya. Suatu komunikasi dibutuhkan juga dalam organisasi dimana dengan adanya komunikasi organisasi yang efektif dapat tercipta suatu efektivitas kerja dalam lingkungan suatu organisasi. Oleh karena itu permasalahan dalam penelitian ini 
adalah "Apakah Hubungan Antara Komunikasi Organisasi Terhadap Peningkatan Kinerja Karyawan PT.Fuji Dharma Electric.” Dan untuk menjawab permasalahan tersebut diajukan hipotesis sebagai berikut:"Ada Hubungan Antara . Komunikasi Organisasi Terhadap Peningkatan Kinerja Karyawan PT.Fuji Dharma Electric.”

Dari hasil perhitungan dan analisis $\mathrm{r}$ Uji $=0,78$ kemudian dilanjutkan dengan nilai t Uji $=6,78$ dan nilai $\mathrm{t}$ Tabel $=1,70$. Hal ini mengisyaratkan bahwa nilai $\mathrm{t}$ Uji lebih besar dari nilai $\mathrm{t}$ Tabel yaitu $6,78>1,70$ pada taraf signifikan 0,05 (5\%). Dengan demikian dapat disimpulkan menolak hipotesis nol (Ho) dan menerima hipotesis alternatif (Ha) yang menyatakan ada hubungan yang signifikan antara Komunikasi Organisasi Terhadap Peningkatan Kinerja Karyawan PT.Fuji Dharma Electric. Selanjutnya menjawab masalah utama pada penelitian ini adalah "Apakah Komunikasi Organisasi Berpengaruh Terhadap Peningkatan Kinerja Karyawan PT.Fuji Dharma Electric" Dan untuk menjawab masalah utama tersebut diajukan hipotesis sebagai berikut: "Komunikasi Organisasi berpengaruh Terhadap Peningkatan Kinerja Karyawan PT.Fuji Dharma Electric.’Dari hasil analisis regresi linear sederhana diperoleh persamaan regresi sebagai berikut : $\mathrm{Y}=2,79+0,88 \mathrm{X}$.

Dari hasil persamaan regresi sederhana ternyata koefisien regresi (koefisien arah b) diperoleh nilai $0,88 \mathrm{X}$, ini menunjukkan bahwa setiap satu variabel Komunikasi Organisasi akan diikuti 0,88 variabel peningkatan kinerja karyawan PT.Fuji Dharma Electric Kemudian hasil arah regresi dari kedua variabel yang dapat dilihat pada tabel ANAVA (Analisis Variens) menunjukkan adanya hubungan Fungsional (Linear) dan berarti atau bermakna antar kedua variabel yaitu antara Peran Komunikasi Organisasi Terhadap Peningkatan Kinerja Karyawan PT.Fuji Dharma Electric.

Selanjutnya variabel antara Pengaruh Komunikasi Organisasi Terhadap Peningkatan Kinerja Karyawan PT Fuji Dharma Electric, dapat dilihat dari hasil koefisien determinasi atau daya penentu dimana hasilnya $\mathrm{R} 2=0,78^{2}=0,61=61 \%$, artinya Pengaruh Komunikasi Organisasi Terhadap Peningkatan Kinerja Karyawan PT Fuji Dharma Electric adalah 46\% sedangkan sisanya $39 \%$ dipengaruhi oleh variabel lainnya yang tidak diteliti dalam penelitian. Hasil penelitian ini dikaitkan dengan teori yang digunakan, adalah . teori yang menjadi landasan penelitian ini adalah menggunakan model transaksional dalam model komunikasi ini memberikan penekanan pada proses pengiriman dan penerimaan pesan yang berlangsung secara terus menerus dalam suatu sistem komunikasi. Dalam mekanisme pengiriman dan penerimaan pesan, proses komunikasi berlangsung secara kooperatif dimana pengirim dan penerima secara bersama-sama bertanggung jawab terhadap ekses/akibat dari proses komunikasi yang berlangsung, apakah efektif atau tidak, karena didalam model ini makna 
dibangun oleh umpan balik dari peserta komunikasi. Model transaksional berasumsi bahwa saat kita terus menerus mengirimkan dan menerima pesan, kita berurusan baik elemen verbal atau non verbal, dengan kata lain peserta komunikasi (komunikator) melakukan proses negosiasi makna.

Dalam model transaksional ini juga terdapat bidang pengalaman, tetapi terjadi perpotongan, dengan demikian pada proses komunikasi yang berlangsung masing-masing menunjukkan proses pemahaman yang terjalin aktif, sehingga timbul suatu pemahaman baru sebagai proses interaksi, intergrasi dan komunikasi diantara masing-asing peserta komunikasi dengan pengalaman yang berbedabeda, Model transaksional yang dikemukakan oleh West \& Turner dikaitkan dengan penelitian ini adalah proses penyampaian pesan pada karyawan PT Fuji Dharma Electric yang bergerak dibidang elektronik sehingga masing-masing karyawan dapat memahami informasi yang disampaikan menggunakan makna dengan pengalamanpengalaman sehingga terjadi proses pemahaman yang terjalin secara aktif dengan karyawan , dan jika karyawan dapat memahami pesan tentang pekerjaan maka mempengaruhi kegiatan organisasi, seperti efisiensi kinerja, karyawan Dengan demikian dapat disimpulkan dari hasil penelitian dan teori menunjukkan bahwa ternyata Pengaruh Komunikasi Organisasi Terhadap Peningkatan Kinerja Karyawan PT Fuji Dharma Electric.

\section{SIMPULAN DAN REKOMENDASI}

Dalam penelitian ini disimpulkan bawa ada hubungan signifikan antara Komunikasi Organisasi Terhadap Peningkatan Kinerja Karyawan PT Fuji Dharma Electric hal ini ditunjukkan melalui Uji $\mathrm{t}$ dimana nilai $\mathrm{t}$ Uji $=6,78$ lebih besar dari nilai $\mathrm{t}$ Tabel $=1,70$.kemudian lebih dipejelas lagi dengan nilai nilai $\mathrm{r}$ Uji $=0,78$ dikonsultasikan pada tabel Guillford menunjukkan hubungan yang "berarti". Hasil penelitian ini berarti bahwa pengaruh variabel komunikasi organisasi berhubungan secara signifikan terhadap peningkatan kinerja karyawan PT Fuji Dharma Electric dimana komunikasi organisasi disini dapat dijelaskan bahwa adanya komunikasi diantara karyawan, keterbukaan informasi, frekuensi berkomunikasi yang sering dilakukan dan adanya suatu kerjasama yang dilakukan oleh karyawan sehingga berhubungan secara signifikan.

Berdasarkan hasil koefisien determinasi atau daya penentu, Komunikasi Organisasi Terhadap Peningkatan Kinerja Karyawan PT Fuji Dharma Electric adalah 61\% sedangkan sisanya 39\% dipengaruhi oleh variabel lainnya yang tidak diteliti dalam penelitian ini. 
Dari hasil analisis regresi linear Pengaruh Komunikasi Organisasi Terhadap Peningkatan Kinerja Karyawan PT Fuji Dharma Electric terdapat hubungan yang fungsional dan linear dan berarti (bermakna) diantara kedua variabel yaitu Komunikasi Organisasi Terhadap Kinerja Karyawan PT Fuji Dharma Electric.

\section{REFERENSI}

1. Cangara, Hafied. 2006. Pengantar Ilmu Komunikasi. Jakarta : PT Raja Grafindo Persada.

2. Creswell, John W. 2010. Edisi ke 3. Research Design : Pendekatan Kualitatif, Kuantitatif, dan Mixed. Yogyakarta : Pustaka Pelajar

3. Hamidi. 2007. Metode Penelitian dan Teori Komunikasi : Pendekatan Praktis Penulisan Proposal dan Laporan Penelitian. Malang: UMM Press.

4. Jumroni, Suhaimi. 2006. Metode-metode Penelitian Komunikasi : Ciputat, UIN Press.

5. Liliweri, Alo. 2014. Sosiologi dan Komunikasi Organisasi. Jakarta: PT Bumi Aksara.

6. Pace, R. Wayne dan Don F. Faules. 1998. Komunikasi Organisasi. Strategi Meningkatkan Kinerja Perusahaan. Bandung : Remaja Rosda Karya

7. Rakhmat, Jalalludin, 2007, Metode Penelitian Komunikasi,PT Remadja Rosda Karya, Bandung

8. Riduwan, 2008, Dasar-Dasar Statistika, Alfabeta Bandung.

9. Sopiah.2008. Perilaku Organisasional. Yogyakarta : Andi Offset.

10. Siagian. P Sondang. 2009. Kiat Meningkatkan Produktivitas Kerja. Jakarta : Rineka Cipta 